\title{
Maculopapular cutaneous mastocytosis
}

INSERM

\section{Source}

INSERM. (1999). Orphanet: an online rare disease and orphan drug data base.

Maculopapular cutaneous mastocytosis. ORPHA:79457

Maculopapular cutaneous mastocytosis (MCM) is a form of cutaneous mastocytosis

(CM; see this term) characterized by the presence of multiple hyperpigmented macules,

papules or nodules associated with abnormal accumulation of mast cells in the skin. 